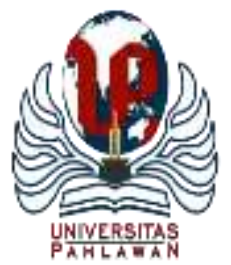

Edukatif : Jurnal Ilmu Pendidikan Volume 3 Nomor 6 Tahun 2021 Halm 5170 - 5182

EDUKATIF: JURNAL ILMU PENDIDIKAN

Research \& Learning in Education

https://edukatif.org/index.php/edukatif/index

\title{
Urgensi Penerapan Outdoor Learning dalam Praktik Pendidikan Lingkungan
}

\author{
Aminah Zuhriyah ${ }^{凶}$ \\ STKIP Kusumanegara, Indonesia \\ E-mail : aminah zuhriyah@ stkipkusumanegara.ac.id
}

\begin{abstract}
Abstrak
Pendidikan lingkungan merupakan komponen penting dalam meningkatkan pengetahuan dan kompetensi siswa dalam berperilaku pro lingkungan. Pengembangan pendidikan luar ruang merupakan penentu keberhasilan pendidikan lingkungan. Dengan demikian belajar dengan alam akan mendukung pengembangan pendidikan berkelanjutan. Penelitian ini bertujuan untuk mengetahui pentingnya dukungan dari pendidikan luar ruang untuk meningkatkan perubahan sikap siswa. Metode yang digunakan adalah fenomenologi kualitatif. Temuan menunjukkan bahwa kegiatan kelas memiliki kemampuan terbatas untuk mengubah beberapa komponen pendidikan lingkungan, terutama hubungan emosional dengan lingkungan (pengaruh) dan perilaku lingkungan. Pendekatan pedagogis luar ruang akan memiliki potensi tinggi untuk mengintegrasikan fitur-fitur utama dan mengomentari beberapa pengalaman yang memberikan kesempatan kepada siswa untuk menjadi agen perubahan di komunitas lokal mereka.
\end{abstract}

Kata Kunci: outdoor learning, pendidikan lingkungan, guru.

\begin{abstract}
Environmental education is an important component in increasing students' knowledge and competence in proenvironmental behavior. The development of outdoor education is a determinant of the success of environmental education. Thus learning with nature will support the development of sustainable education. This study aims to determine the importance of support from outdoor education to increase student attitude change. The method used is qualitative phenomenology. The findings indicate that classroom activities have a limited ability to change several components of environmental education, especially emotional relationships with the environment (influence) and environmental behavior. The outdoor pedagogical approach will have high potential to integrate key features and comment on some of the experiences that provide students with opportunities to become agents of change in their local communities.
\end{abstract}

Keywords: outdoor learning, environmental education, teacher.

Copyright (c) 2021 Aminah Zuhriyah

$\triangle$ Corresponding author:

Email : aminah zuhriyah@stkipkusumanegara.ac.id

ISSN 2656-8063 (Media Cetak)

DOI : https://doi.org/10.31004/edukatif.v3i6.1662

ISSN 2656-8071 (Media Online)

Edukatif : Jurnal Ilmu Pendidikan Vol 3 No 6 Tahun 2021 p-ISSN 2656-8063 e-ISSN 2656-8071 


\section{Urgensi Penerapan Outdoor Learning dalam Praktik Pendidikan Lingkungan - Aminah Zuhriyah}

DOI: https://doi.org/10.31004/edukatif.v3i6.1662

\section{PENDAHULUAN}

Pengaturan pendidikan lingkungan melalui penerapan pembelajaran di luar ruangan akan mendukung terciptanya pembangunan pendidikan yang berkelanjutan. Menggali cara pembelajaran melalui permainan alam dan konsep keberlanjutan sangat penting dan dapat dikembangkan dan dilakukan oleh mahasiswa muda ataupun siswa dalam perjalanannya untuk menjadi warga dunia. Fokus ini harus didasarkan pada konsep pengembangan nilai dan pedagogi untuk anak-anak yang menghubungkan alam untuk bermain dengan keberlanjutan. Contoh-contoh praktis dari pedagogi yang berhasil disajikan, diikuti dengan rekomendasi bagi para guru untuk mencapai tujuan yang dapat meningkatkan kontak dengan alam terutama dalam pendidikan anak usia dini. Pada tahapan awal ini merupakan tiangterpenting untuk memberikan pemahaman baru yang terkait dengan perilaku pro lingkungan.

Dengan memelihara dan meningkatkan lingkungan mereka, siswa yang sukses memahami tempat mereka sebagai warga lokal dan global, melestarikan dan meningkatkan lingkungan alam dan sosial secara seimbang.Untuk itulah, kepentingan global pendidikan pada tahun-tahun awal tidak boleh dianggap remeh, karena di sinilah fondasi pandangan dunia peserta didik, yang dimediasi oleh sekolah harus didirikan dengan kuat. Setiap orang sendiri membutuhkan seperangkat keyakinan yang memungkinkan untuk menyediakan kerangka kerja dalam menafsirkan dunia, adalah cara yang berharga untuk mengkonseptualisasikan pengalaman anak terutama sejak usia dini. Penting, pada tahap awal ini untuk memastikan bahwa semua anak memiliki pengalaman terluas di dunia yang dapat diberikan. Misalnya saja, mengambilnya di luar batas kelas dan sekolah, fisik dan imajinatif, serta memberikan kesempatan untuk memperluas pengalaman dengan berinteraksi langsung dengan alam sekitarnya (Haas \& Ashman, 2014).

Pengembangan kerangka kualitas pembelajaran luar ruang yang mengungkapkan apa yang ada antara teori dan praktik, dikombinasikan dengan upaya untuk mendukung anak-anak menjadi bertanggung jawab terhadap lingkungan merupakan salah satu strategi guru untuk mengubah perilaku siswa menuju pro lingkungan. Menekankan pentingnya mendengarkan suara anak-anak, pendekatan 'whole-of-the-art', dan terlibat dalam refleksi tentang isu-isu keberlanjutan dan pendidikan lingkungan. Banyak para pendidik yang tidak menyadari, atau kewalahan oleh isu-isu keberlanjutan tersebut selama bertahun-tahun, menyebabkan pengajaran mereka masih bersifat formatif dan tidak lengkap (kurang) serta bersifat jangka pendek (Pollock et al., 2017).

Upaya penting yang dapat dikembangkan antara lain; misalnya pengembangan taman berbasis sekolah dalam pembelajaran outdoor. Manfaatnya bagi siswa yang menanam tanaman pangan di halaman sekolah mereka akan mencerminkan prinsip-prinsip pendidikan global dengan mencontohkan keberlanjutan melalui tanggung jawab mereka dalam perencanaan ekologis dan pelayanan kepada masyarakat, lingkungan dan kemanusiaan.Pendekatan pedagogis sendiri adalah kerangka kerja penting untuk perencanaan taman sekolah dan pengalaman terkait yang menunjukkan bagaimana taman sekolah dapat mempromosikan kesehatan, kebiasaan makan sehat, praktik lokal berkelanjutan yang berdampak pada ekonomi global, dan layanan kepada masyarakat sekitar secara luas. Pengetahuan tentang budaya, sumber daya lokal dan global, serta sumber makanan berkelanjutan yang sering diintegrasikan ke dalam program taman sekolah tersebut, terbukti menjadi program yang sukses. Peduli terhadap masyarakat, satu sama lain di sekolah, dan untuk planet ini adalah hasil yang mungkin dicapai untuk prospek jangka panjang. Di beberapa situasi sendiri, taman sekolah memberi siswa kesempatan langsung untuk memperluas apa yang mereka pelajari langsung dari sumber makanan berkelanjutan ke dalam layanan yang memengaruhi ketersediaan makanan segar dan sehat di lokasi di mana faktor sosial ekonomi sering kadang kala bertentangan dengan akses keluarga terhadapnya. Dengan demikian, peran sekolah sebagai penengah informasi yang tepat guna dalam mengkampanyekan pendidikan lingkungan yang sesuai dengan tujuan pembangunan berkelanjutan.

Kebun atau taman sendiri merupakan bagian integral dari budaya manusia, mereka bukan kemenangan perencanaan manusia atas alam, melainkan mewakili kolaborasi dengan alam ketika mereka berhasil 


\section{Urgensi Penerapan Outdoor Learning dalam Praktik Pendidikan Lingkungan - Aminah Zuhriyah DOI: https://doi.org/10.31004/edukatif.v3i6.1662}

dibayangkan, dieksekusi, dan dieksploitasi. Eksplorasi taman di halaman sekolah dan sekitarnya, berkontribusi pada perasaan bagaimana pekerjaan seseorang di lapangan berkontribusi pada cara global untuk terhubung dengan alam (Wolsey, 2014). Taman - taman di sekolah telah memberikan banyak kesempatan untuk pendidikan terpadu dalam pendidikan untuk pembangunan berkelanjutan (ESD). Mereka biasanya terletak di halaman sekolah atau di dekatnya. Mereka memiliki bentuk dan ukuran yang berbeda dan melayani berbagai tujuan baik seperti studi, rekreasi, dan produksi makanan. Taman sekolah memiliki tradisi panjang sebagai wahana tempat belajar. Tergantung pada daerahnya, mereka dibuat berbeda dalam tujuannya. Di Eropa saja misalnya, taman sekolah sebagian besar berfungsi sebagai laboratorium luar ruang untuk sains, studi lingkungan, dan mata pelajaran lainnya. Baru-baru ini saja, hubungan kembali anak muda dengan alam dan asal usul makanan mereka telah muncul sebagai tujuan baru dalam pendidikan berkebun di beberapa sekolah di dunia. Salah satu contoh lainnya seperti di Amerika dan Afrika misalnya, fokusnya lebih pada "pertanian kejuruan", pelatihan dan produksi pangan untuk konsumsi atau uang tunai" (Lochner \& Robischon, 2015).

Diakui secara luas bahwa pendidikan memang memainkan peran kunci dalam mengatasi berbagai tantangan global saat ini. Education for Sustainable Development (ESD) menggabungkan aksi lokal dengan pemikiran global. Pentingnya pendidik bertujuan untuk mempromosikan pengetahuan tentang berkebun dan kompetensi pangan, hortikultura dan kerjasama, serta nilai-nilai seperti solidaritas. Education for Sustainable Development yaitu hasil belajar dan pengaturan pembelajaran ESD yang diharapkan dapat membekali siswa dengan pengetahuan, kompetensi, dan nilai-nilai yang dibutuhkan untuk berkontribusi pada pembangunan berkelanjutan. Pengembangan nilai dianggap penting bagi ESD, karena nilai tersebut membantu mengatasi masalah global saat ini dan masa depan serta tantangan local yang ada. Konsep transformatif pembelajaran dengan pendidikan luar ruang menjawab pertanyaan bagaimana perubahan nilai siswa dapat terjadi dalam kerangka ESD (Lochner, 2021)

Oleh karena itu, penting untuk menerapkan pendidikan luar ruang sebagai metode pembelajaran yang efektif untuk meningkatkan perubahan siswa menuju sikap pro-lingkungan. Siswa yang dapat berinteraksi langsung dengan lingkungan alam akan berbeda pemahamannya dengan siswa yang hanya belajar di dalam kelas baik berdasarkan buku, teori atau modul lainnya.Novelty (keterbaruan) dari penelitian ini sesuai dengan pandangan peneliti bahwa penggabungan dari konsep pendidikan luar ruang (outdoor learning) sebagai komponen utama pendukung yang tidak dapat terpisahkan dengan strategi pengembangan pendidikan lingkungan. Hal ini dikarenakan banyak peneliti lainnya yang hanya menfokuskan ke satu konsep teori saja seperti dalam membahas focus ke kajian pendidikan lingkungan saja. Untuk itulah agar dapat memaksimalkan proses pembelajaran pendidikan lingkungan tersebut peneliti berusaha menggabungkan konsep strategi pembelajaran luar ruang yang terkait dengan pandangan bahwa seharusnya siswa harus dapat melihat dan merasakan secara langsung fenomena - fenomena yang terjadi di alam sekitarnya. Dengan demikian, bukan hanya perubahan dari segi pemahaman informasi berupa kognitif saja, melainkan juga afeksi (emosional) dan tindakan yang lebih selaras dengan bumi. Guru yang berperan penuh sebagai pembimbing dan fasilitator menjadi jembatan informasi dalam mendukung proses pembelajaran luar ruang tersebut. Kreatifitas dan inovasi yang didapatkan siswa dari proses pembelajaran luar ruang dari guru akan menjadi penentu keberhasilan kurikulum pendidikan lingkungan.Hal ini sejalan dengan pendapat dari (Zebua \& Siahaan, 2021) yang mengatakan bahwa kinerja guru yang melakukan pembelajaran dengan metode klasik akan menurunkan minat belajar siswa yang berujung pada penurunan ide dan kreatifitas siswa. Para siswa ini akan cepat merasa jenuh dan tidak tertarik dengan proses belajar- mengajar yang dilakukan. Untuk itulah guru harus jeli dalam melihat peluang apa saja yang harus diterapkan agar dapat mengelola kelas dengan efektif dan efisien. Salah satunya dengan pendekatan pembelajaran yang menarik sehingga menciptakan dampak positif bagi perkembangan minat belajar siswa.

Peran guru disini menjadi sangat krusial menjadi penentu dalam keberhasilan dalam mengubah perilaku dan karakter dari siswa. Guru bukan hanya sebagai pemberi materi pelajaran, melainkan juga sebagai 


\section{Urgensi Penerapan Outdoor Learning dalam Praktik Pendidikan Lingkungan - Aminah Zuhriyah DOI: https://doi.org/10.31004/edukatif.v3i6.1662}

penghubung dalam transformasi pengetahuan secara aktif agar membentuk perilaku siswa yang sesuai dengan harapan serta didukung dengan perubahan kesadaran diri secara positif (Pradina \& Faiz, 2021). Pondasi yang diberikan dari guru dalam mengarahkan siswa harus selalu dipantau agar tidak terjadi dampak negative bagi pola tumbuh dan perilaku siswa tersebut. Pentingnya pemilihan strategi pembelajaran sekolah dasar yang tepat guna dalam memberikan solusi untuk jangka panjang agar siswa tidak mudah terpengaruh dalam lingkungan yang negative (Khusna et al., 2021).

Lalu, apabila dikaitkan dengan kajian fenomena yang terjadi hingga saat ini, terutama dimana terjadi gesekan - gesekan pada kondisi lingkungan alam yang semakin menurun drastis diakibatkan kurang kesadaran akan lingkungan dari masing - masing individu dalam menjaga lingkungan bumi yang mengakibatkan berbagai penurunan kualitas lingkungan hidup di beberapa daerah khususnya di negara Indonesia sendiri. Bencana alam yang terjadi salah satunya adalah bencana banjir yang sering melanda di kawasan Jabodetabek. Salah satu pada kawasan sekolah yang terkena dampak fenomena banjir ini yakni Sekolah Islam Al-Fajar Bekasi.

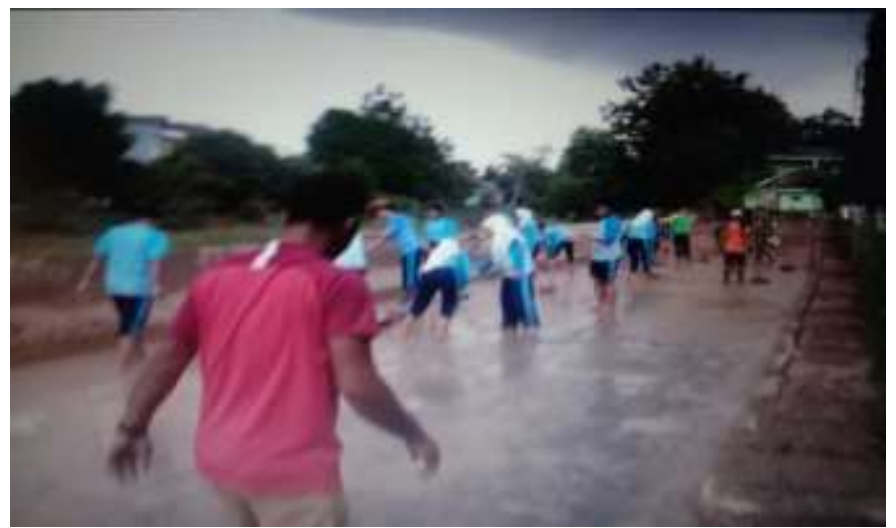

\section{Gambar 1. Kegiatan Gotong Royang dalam Membersihkan Bekas Banjir (Sekolah Islam Al Fajar,} 2019)

Sekolah ini merupakan salah satu sekolah swasta yang dikelola oleh yayasan Darul Fajar yang mempunyai misi dalam mengutamakan integrasi nilai - nilai islam serta menciptakan generasi muda yang berakhlak mulia baik disegala bidang terutama berhasil dalam menjaga lingkungan alam sekitarnya. Hal tersebut dapat terlihat pada gambaran diatas para siswa saling bahu-membantu dalam kegiatan membersihkan lingkungan sekolah akibat banjir tersebut. Peran aktif para murid dan guru ini membuktikan bahwa pengelolaan sekolah yang tepat dalam menjaga lingkungan akan mendukung terciptanya keseimbangan tujuan dari pembangunan berkelanjutan.

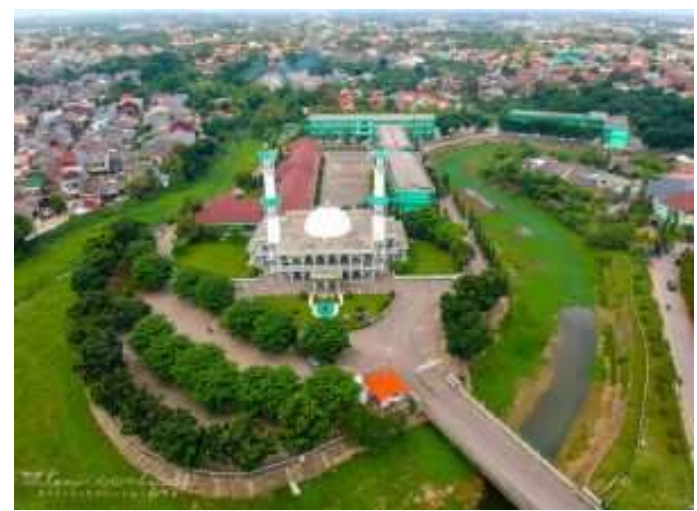

\section{Gambar 2. Kompleks Terpadu Sekolah Islam Al Fajar Bekasi (Sekolah Islam Al Fajar, 2019)}

Sekolah sebagai role model dalam percontohan sekolah lainnya untuk dapat memulai perubahan kearah yang lebih baik. Bukti nyata yang dihasilkan dari Sekolah Al Fajar ini pun sesuai dengan komitmen lingkungan yang dilakukannya yakni berhasil mendapatkan penghargaan adiwiyata sekolah sebagai bukti 


\section{Urgensi Penerapan Outdoor Learning dalam Praktik Pendidikan Lingkungan - Aminah Zuhriyah DOI: https://doi.org/10.31004/edukatif.v3i6.1662}

kontribusi penuh yang positif dalam mengelola lingkungan alam secara tepat sasaran. Kolaborasi aktif yang dilakukan oleh pihak sekolah ini telah membuktikan bahwa dukungan penuh secara aktif dari semua komponen terkait dan regulasi yang tepat guna akan mendukung terciptanya strategi pembelajaran pendidikan lingkungan yang efektif. Atas dasar itulah, penulis tertarik melakukan kajian fenomena yang terjadi di sekolah terhadap pelaksanaan pendidikan luar ruang guna mengetahui secara mendalam sejauh mana peran pendidikan luar ruang sebagai penentu keberhasilan pelaksanaan pendidikan lingkungan hidup di sekolah yang dibuktikan dengan temuan sekolah yang telah berhasil dalam menerapkan pendidikan luar luar sebagai pendukung penuh bagi keselarasan kurikulum pendidikan lingkungan.

\section{METODE PENELITIAN}

Metode yang digunakan dalam penelitian ini adalah kualitatif dengan pendekatan fenomenologis. Metode ini digunakan karena penulis ingin memahami bagaimana kedalaman dan kekayaan makna pengalaman manusia dapat diukur, digali, dan dibawa ke dalam bahasa yang lebih mendalam (Adams \& Van Manen, 2017). Lokasi penelitian yang diambil yakni di Provinsi Jawa Barat pada Sekolah Al Fajar Bekasi yang dimulai dari bulan Juli 2019 - Maret 2020. Pada penelitian ini menggunakan teknik pengumpulan data dengan studi dokumentasi, observasi dan wawancara mendalam. Instrumen penelitian yang dipakai yakni panduan wawancara yang digunakan dalam proses pencarian data lapangan. Kriteria dalam pengambilan sampel dilakukan dengan purposive sampling dikarenakan responden yang akan dijadikan narasumber kunci merupakan pelaku aktif yang paham akan fenomena yang akan dikaji antara lain yakni; (1) Kepala Sekolah Al-Fajar, (2) Guru, (3) Murid, dan (4) Orang tua Murid. Proses pengambilan data saat wawancara berlangsung dengan melakukan rekaman suara dan pencatatan atas kesukarelaan (tanpa paksaan) dari masing - masing responden kunci. Setelah selesai proses rekaman suara tersebut, dilakukan re-evaluasi transkripsi data rekaman dan pencatatan ulang untuk menguji keabsahan data yang diperoleh dengan teknik open coding. Lalu langkah terakhir, barulah melakukan sintesis akhir dari hasil temuan - temuan yang diambil dengan kajian yang diangkat.

\section{HASIL DAN PEMBAHASAN PENELITIAN}

Berdasarkan hasil temuan dari keempatresponden kunci terkait kajian pendidikan luar ruang yang menjadi penentu keberhasilan dalam mendukung kurikulum pendidikan lingkungan yang efektif dan efisien, hal ini dikarenakan komitmen lingkungan yang dicanangkan oleh sekolah menjadi sebuah kebijakan yang mengikat seluruh komponen anggota sekolah. Alhasil, sekolah tersebut dapat memaksimalkan potensi sekolahnya dengan tetap mendukung proses belajar mengajar kearah pro lingkungan. Peran aktif dari para guru menjadi penentu dalam perkembangan pendidikan luar ruang. Namun, penting diingat bahwa kolaborasi yang dilakukan bukan hanya untuk skala internal sekolah saja, melainkan peran sekolah menjadi pencetus sekolah luar ruang berbasis lingkungan yang dapat menjangkau pihak eksternal. Kondisi ini akan memungkinkan siswa bukan hanya melakukan peran aktifnya di kelas saja, melainkan mereka juga dapat berbagi ilmu dan ide briliant dengan keluarganya baik orangtua mereka sendiri, tetangga, teman, serta khalayak umum (masyarakat) lainnya. Siswa akan bertransformasi menjadi agen perubahan yang membawa budaya baru dalam maraknya perubahan dinamis untuk mengelola lingkungan bumi secara seimbang dalam aspek social, ekonomi dan lingkungan alam yang sejalan dengan tujuan utama dari pembangunan berkelanjutan. 


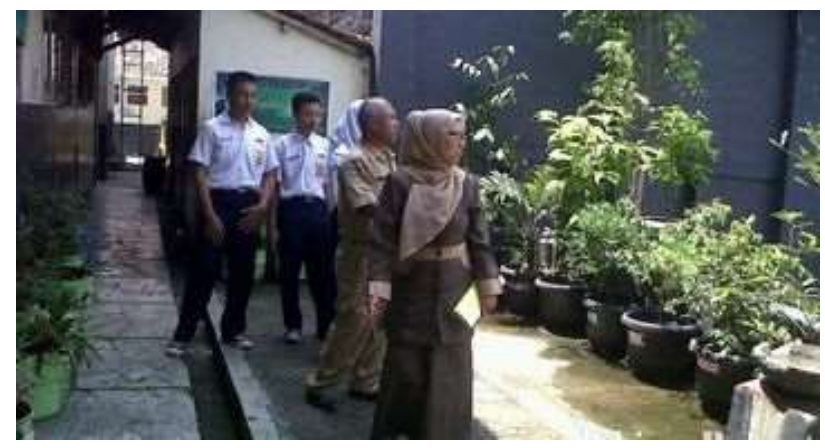

Gambar 3. Taman Sekolah Sekolah Islam Al Fajar Bekasi (Sekolah Islam Al Fajar, 2019)

Pelajaran penting yang didapat dari pendidikan luar ruang akan semakin membuka wawasan baru siswa untuk lebih menjaga dan berpikir secara mendalam bahwa segala tindakan yang dilakukan kepada alam sekitar akan mengakibatkan dampak baik itu hasil yang positif dan negative. Peran orang tua khususnya dirumah yang mendukung pola pendidikan ini akan semakin memperkuat pola tindakan yang dilakukan oleh siswa tersebut. Fenomena yang marak saat ini sering kali para orang tua ini terkesan tidak peduli dengan apa yang dilakukan oleh anak mereka di sekolah. Mereka menyerahkan segala macam tanggung - jawab penuh bagi para guru di sekolah. Sehingga, terkadang kondisi ini jelas tidak mendukung kolaborasi penuh semua pihak terkait atau menjadi salah satu factor penghambat terbentuknya perubahan sikap pro lingkungan tersebut. Untuk itulah pihak sekolah Al Fajar berupaya untuk sering melakukan pertemuan rutin dengan lingkup diskusi bersama orang tua murid untuk semakin memperkuat hubungan kekeluargaan dalam mendukung terciptanya perubahan yang lebih baik. Pihak sekolah yang diwakili oleh para guru kelas ini terus mengoptimalkan komunikasi dua arah antara siswa dan orang tua. Hal ini akan semakin mendukung terwujudnya perubahan sikap siswa secara aktif dengan mendengarkan segala macam saran dan masukan terkait kondisi yang ada. Sekolah sebagai fasilitator pendamping yang menjembatani segala macam permasalahan yang terjadi dalam memaksimalkan peran pendidikan luar ruang untuk peningkatan kesadaran lingkungan dari masing - masing siswa dengan tetap berkoordinasi dengan orang tua murid agar saling mendukung proses pembelajaran lingkungan yang dilakukan. Walaupun memang terkadang terdapat kendala dalam meyakinkan pihak orang tua murid, namun komitmen aktif yang dilakukan oleh sekolah telah menjadi sebuah janji yang menjamin keseriusan program pembelajaran yang dilakukan untuk masa depan jangka panjang.

Pendidikan lingkungan secara signifikan didasarkan pada pengalaman hidup, yang mempelajari pengaruh yang membentuk pengembangan kepedulian lingkungan. Peran keluarga, yaitu orang tua, juga menjadi asumsi yang mendasari dalam mengungkap pengalaman signifikan dalam program pendidikan lingkungan. Pengaruh lingkungan sekolah terhadap orang tua akan semakin mendukung program pendidikan lingkungan. Potensi peran siswa sekolah lingkungan dalam mempengaruhi komunitas mereka akan menentukan efektivitas program pembelajaran ini. Jika proses ini memang terjadi, wajar jika lingkungan sekolah menjadi salah satu pengaruh formatif bagi orang tua anak yang belajar di sekolah (Eilam \& Trop, 2014).

Kebanyakan orang tua dipengaruhi oleh tuntutan anak-anak mereka untuk terlibat dalam aksi prolingkungan, yang mereka pelajari sebagai bagian dari program Eco-Schools. Selain itu, beberapa orang tua menganggap anak-anak mereka memiliki hak untuk mendiskusikan masalah lingkungan dan berusaha memberdayakan mereka untuk memperoleh keterampilan pengelolaan lingkungan, tetapi yang lain tidak. Temuan ini memberikan wawasan tentang kemampuan langsung dan tidak langsung anak-anak untuk mempengaruhi tindakan orang dewasa terhadap kelestarian lingkungan.

Jika anak-anak kecil ingin menjadi agen perubahan lingkungan yang diberdayakan untuk mengubah dunia di sekitar mereka, pendidikan perlu membekali mereka dengan alat dan keterampilan untuk mencapai tujuan ini melalui pengembangan pembelajaran berbasis alam. Kaum muda yang menjadi agen perubahan lingkungan adalah mereka yang memiliki keinginan untuk hidup berkelanjutan dan termotivasi untuk 


\section{Urgensi Penerapan Outdoor Learning dalam Praktik Pendidikan Lingkungan - Aminah Zuhriyah DOI: https://doi.org/10.31004/edukatif.v3i6.1662}

mempengaruhi orang tua mereka untuk mengadopsi cara hidup ini. Dengan demikian, diakui bahwa anak kecil akan tumbuh menjadi orang dewasa yang bertanggung jawab dan mereka mampu mempengaruhi keputusan yang dibuat orang dewasa (Spiteri, 2020).

Pengalaman masa kanak-kanak tentang alam memiliki efek seumur hidup pada lingkungan sipil dan komitmen terhadap kegiatan berbasis alam. Untuk itu, komitmen terhadap kegiatan berbasis alam, menjadi penentu dalam pengalaman lingkungan nyata yang akan menjadi gambaran model untuk masa depan. Paparan alam memungkinkan anak-anak dan remaja untuk terlibat dalam kegiatan yang mempromosikan pengembangan pribadi dan keterampilan sosial. Anak-anak di lingkungan yang lebih hijau telah terbukti memiliki lebih sedikit masalah emosional dibdaningkan dengan anak-anak dari demografi yang sama di lingkungan yang kurang hijau. Paparan terhadap alam meningkatkan kedekatan emosional anak-anak dan remaja dengan alam, kepercayaan ekologis mereka, dan kesediaan mereka untuk terlibat dalam perilaku prolingkungan. Dalam jangka panjang, keterpaparan masa kanak-kanak dengan alam mengarah pada komitmen orang dewasa terhadap aktivitas berbasis alam (Asah et al., 2018).

Keberhasil kebijakan atau regulasi berbasis lingkungan yang terapkan oleh Kepala Sekolah Al Fajar sendiri juga didasarkan dengan komitmen nyata yang dilakukan pada aktifitas sehari- harinya. Mulai dari tindakan kecil yang dilakukan sehari - hari kemuadian akan berlanjut menjadi sebuah rutinitas yang menjadi kewajiban. Dengan demikian, seluruh anggota sekolah mau tidak mau akan mengikuti dan melakukan segala macam aturan yang telah ditetapkan. Budaya ini pun terus dijalankan secara terus - menerus sehingga menjadi satu ciri khas yang diingat bagi para anggota komunitas sekolah terutama pada pada ada anggota baru masuk ke komunitas ini.Peran penting dari kepala sekolah sebagai pemegang kebijakan utama akan menjadi penentu dalam startegi penerapan pendidikan luar ruang ini. Mereka adalah orang yang berkomitmen penuh dan bertanggung jawab dalam upaya mendorong seluruh anggota sekolah untuk mengubah perilakunya akan semakin mendukung pendidikan lingkungan yang efektif.

Dukungan masyarakat sekolah dalam perilaku hemat energi yang dilakukan dengan menggunakan transportasi umum akan mendukung konsep pendidikan lingkungan. Upaya individu yang dilakukan dengan perilaku pro lingkungan akan mendukung keberhasilan pembelajaran berbasis lingkungan. Perubahan ini diakui bergantung, sebagian, pada pergeseran cara orang berpikir tentang dan menggunakan energi, dan kesediaan mereka untuk mengadopsi atau memfasilitasi intervensi dan kebijakan yang ditujukan untuk mengurangi permintaan energi. Untuk itulah peran sekolah disini berkontribusi dalam menciptakan pendidikan lingkungan yang berkualitas sangat didukung dengan penerapan pendidikan luar ruang tersebut bukan hanya untuk lingkup internal saja melainkan juga lingkup eksternal secara lebih luas (Kaklamanou et al., 2015).

Upaya nyata yang hingga saat ini masih dilakukan pihak Sekolah Al Fajar sendiri dalam meminimalkan penggunaan energy dengan tindakan untuk menggunakan dan membawa botol (wadah) minuman sendiri selama melakukan aktifitas di sekolah. Sekolah juga memfasilitasi sumber air minum mineral di setiap sudut sekolah untuk membantu sosialiasi kampanye hemat energy di sekolah. Sekolah melarang siswa untuk membeli minuman kemasan karena selain berdampak negatif pada penambahan limbah plastik kemasan juga merupakan sikap boros yang tidak baik. Hal ini akan mengajarkan siswa bahwa fenomena krisis air yang berada di daerah selain Jabodetabek, seperti krisis air yang terjadi di kawasan Indonesia Timur dan kawasan lain di belahan dunia harus ditanggapi dengan serius dalam bentuk aksi nyata bagi pengelolaan lingkungan. Keprihatinan yang dilakukan dengan sikap empati yang tinggi untuk upaya meminimalkan penggunaan energy sumber daya air sebagai bukti perilaku pro lingkungan.

Lembaga pendidikan sains di luar sekolah, seperti museum, pusat sains, kebun binatang, dan akuarium, terbukti memang memiliki potensi kuat untuk mendorong keberlanjutan. Meskipun dalam mencapai keberlanjutan dalam skala global adalah tugas yang sangat berat, namun pendidikan telah diidentifikasi sebagai sarana penting untuk mencapai tujuan ini. Bentuk pendidikan ini disebut pendidikan berkelanjutan, juga disebut dalam literatur sebagai pendidikan untuk pembangunan berkelanjutan dan pendidikan untuk 


\section{Urgensi Penerapan Outdoor Learning dalam Praktik Pendidikan Lingkungan - Aminah Zuhriyah DOI: https://doi.org/10.31004/edukatif.v3i6.1662}

keberlanjutan. Kompleksitas ini antara lain berarti bahwa versi pengetahuan yang ditemukan di lembaga pendidikan tidak selalu optimal dikarenakan salah menafsirkan pemahaman terserbu. Sebagai contoh saja, pameran eksplorasi ruang angkasa secara tidak sengaja telah 'mewarisi' gender maskulin yang ditemukan dalam domain ilmiah astronomi dan teknologi ruang angkasa, meskipun ditujukan untuk audiens di seluruh spektrum gender. Untuk itu peran guru sebagai pendamping harus terus mengarahkan siswa dalam memahami hal tersebut untuk kesetaraan gender yang tidak memberikan citra bahwa dominan hanya untuk pihak pria saja. Guru harus selektif dan jeli dalam menyampaikan informasi sesuai dengan tujuan utama pendidikan sebagai keberlanjutan bagi semua orang (Evans \& Achiam, 2021).

Reid et al., (2021) menemukan bahwa pendidikan sebagai strategi kunci dalam mendukung perubahan perilaku yang diperlukan untuk mengatasi tren tersebut. Pendidikan lingkungan hidup merupakan komponen inti dari semua sistem pendidikan di semua jenjang, dan berpeluang mendapatkan dukungan multilateral dan multilevel sehingga sangat dibutuhkan. Akhirnya, transformasi masyarakat diperlukan secara global, dengan para pemimpin, pemerintah, dan semua orang-orang tersebut. Perubahan tersebut termasuk misalnya, mengadvokasi pengurangan kemiskinan dan akhirnya pengentasan kemiskinan, memastikan kesetaraan gender, dan memastikan kontrol perempuan atas keputusan reproduksi mereka sendiri.

Waktu yang dihabiskan anak-anak di alam telah sangat berkurang karena perkembangan zaman dan penggunaan teknologi. Sementara pembelajaran berbasis alam di sekolah dianggap sebagai strategi penting dalam mengatasi hal ini, banyak kesenjangan pengetahuan yang terus ada. Untuk alasan ini, sebuah gerakan baru untuk menghubungkan kembali anak-anak dengan alam telah muncul. Gerakan ini difokuskan untuk melibatkan anak dalam kegiatan bermain dan belajar yang berbasis alam, khususnya di lingkungan sekolah. Seperti salah satunya di sekolah Al Fajar ini yang berusaha memfasilitasi para siswanya untuk melakukan kegiatan kunjungan luar sekolah baik ke taman konservasi maupun ke lokasi hutan raya. Komitmen lingkungan yang dilakukan sekolah ini akan menjadi solusi dalam pencapaian pendidikan lingkungan yang lebih optimal.

Hal ini dikarenakan seperti kita ketahui bahwa makin tahun anak - anak semakin kurang peka terhadap alam sekitarnya baik hewan dan tumbuhan. Selain diakibatkan punahnya hewan dan tanaman tertentu dan juga kekhawatiran lain bahwa anak - anak hanya dapat melihat dari buku atau gambar saja. Ini mungkin akibat dari pengurangan waktu yang dihabiskan anak-anak saat ini di luar rumah dibandingkan dengan generasi sebelumnya (Miller et al., 2021).

Hal ini jelaslah menimbulkan kekhawatiran bahwa anak-anak kehilangan manfaat potensial dari lingkungan alam, termasuk kesempatan untuk meningkatkan kesehatan fisik dan mental dan membentuk hubungan dengan alam. Dengan demikian, penting untuk dipahami bahwa pembelajaran berbasis alam merupakan komponen penting keberhasilan dalam pendidikan lingkungan. Menerapkan outdoor learning yang akan memberikan kesempatan kepada sekolah untuk terus berupaya membina hubungan baik anak-anak yang terlibat dengan alam. Melalui kegiatan sekolah hutan yang teratur dan berulang dalam suasana alam di hutan sekolah, anak-anak menjadi lebih santai, mengatasi rasa takut, bersenang-senang berhubungan dengan alam saat mereka mengenalnya lebih baik, dan mengembangkan ketertarikan terhadap lokasi. Selanjutnya, mereka mengembangkan rasa memiliki dan kepedulian terhadap lingkungan sekolah hutan dan keinginan untuk melindunginya. Bagi beberapa praktisi sekolah hutan, dan pendidik lainnya, ini akan menumbuhkan hubungan dengan alam dan tempat, dan mengembangkan perilaku pro-lingkungan, yang merupakan bagian mendasar dari praktik mereka. Namun, memang tidak dapat dipungkiri bahwa akibatnya maraknya muatan kurikulum sekolah di Indonesia terutama pada sekolah - sekolah negeri yang mengakibatkan pengaturan jadwal untuk pendidikan luar ruang menjadi terbatas, malah hanya dapat dilakukan satu pekan saja dalam satu semester. Berbeda dengan sekolah swasta yang sudah mengelola jadwal yang dapat disesuaikan dengan muatan kurikulum khususnya dalam aktifitas tambahan atau utama dalam pendidikan luar ruang. Hal inilah yang harus dipahami dengan tepat oleh pihak sekolah dalam mengatur kebijakan dalam pengaturan kurikulum tersebut. 


\section{Urgensi Penerapan Outdoor Learning dalam Praktik Pendidikan Lingkungan - Aminah Zuhriyah DOI: https://doi.org/10.31004/edukatif.v3i6.1662}

Pentingnya pengembangan, harmonisasi kurikulum dan taman, serta merancang pembelajaran berbasis taman untuk mendukung dampak praktis dan teoritis dalam pendidikan lingkungan. Intinya adalah peran sekolah dalam mengembangkan rasa ingin tahu yang mendalam tentang pembelajaran berbasis taman. Sekolah harus dengan sengaja merancang, mewujudkan, merefleksikan, dan terkadang menentang pemikiran dan tindakan manusia dalam mengintegrasikan pembelajaran berbasis taman. Pada saat yang sama, baik sekolah maupun berkebun mempunyai kendala dan keterbatasan yang sering melemahkan upaya untuk mengubahnya. Pengaturan sekolah untuk memeriksa peran desain dalam mengatur, meningkatkan, dan pada akhirnya mendorong pengajaran dan pembelajaran dalam Pendidikan Lingkungan (Zuiker \& Riske, 2021).

Untuk itu, peran sekolah dalam memberikan kesempatan kepada anak untuk belajar tentang alam dan alam bebas melalui pembelajaran terbuka semakin penting untuk dilakukan sejak awal. Beberapa penelitian lain juga menunjukkan bahwa pertemuan dan pengalaman individu dengan alam dapat membuka jalan bagi perilaku lingkungan, dan waktu yang dihabiskan di alam ketika muda dapat memiliki dampak yang bertahan lama pada sikap anak-anak terhadap lingkungan alam sepanjang hidup mereka. Diyakini bahwa mengembangkan ikatan dengan suatu tempat, melalui pengalaman positif, akan menginspirasi anak-anak untuk belajar tentang lingkungan, dan pada akhirnya ingin melindunginya (Harris, 2017)

Dengan demikian, kunjungan rutin siswa dan komunitas sekolah ke ruang hijau akan semakin meningkatkan promosi keanekaragaman hayati, pengetahuan, dan mendukung konservasi. Peningkatan kunjungan ke ruang hijau juga mendorong minat dan pengetahuan tentang keanekaragaman hayati dan dukungan untuk konservasi, yang pada gilirannya semakin meningkatkan keinginan untuk mengunjungi ruang hijau dan mengalami alam (Coldwel \& Evans, 2017)

Seperti dipahami saat ini berbagai program penghijauan yang marak dilakukan di perkotaan khusunya di kota Jakarta sendiri sudah mengarahkan agar komunitas warga untuk sadar akan kerusakan lingkungan yang terjadi. Pengelolaan lahan - lahan yang potensial untuk menjadi Ruang Terbuka Hijau sudah menjadi keharusan yang dilakukan baik di pemerintah kota dan kabupaten untuk mendukung terciptanya tatanan kota yang ramah lingkungan. Pemerintah Indonesia sendiri bekerja sama dengan lembaga pendidikan/ sekolah lainnya sebagai garda utama untuk mempromosikan sikap pro lingkungan bagi para siswa.

Guru yang berpartisipasi mendukung proyek pembelajaran sebagai pengalaman belajar yang positif bagi siswa mereka. Oleh karena itu, keterlibatan dengan kegiatan di luar ruangan akan dapat meningkatkan pengalaman anak-anak dengan alam di daerah perkotaan dengan gabungan dampak lingkungan yang positif. Bukti dari pengalaman masa kanak-kanak dapat secara positif mempengaruhi sikap dan perilaku lingkungan orang dewasa. Dengan demikian, pengetahuan lingkungan dapat memfasilitasi pembentukan sikap (White et al., 2018).

Aktivitas di kelas sendiri diakui memiliki kemampuan terbatas untuk mengubah beberapa komponen pendidikan lingkungan, terutama hubungan emosional dengan lingkungan (pengaruh) dan perilaku lingkungan. Untuk alasan ini, pendidikan lingkungan luar ruang telah dipromosikan sebagai solusi untuk tantangan ini. Waktu di luar ruangan telah dikaitkan dengan komponen afektif yang merupakan prediktor utama perilaku pro-lingkungan yang secara langsung dapat merubah perilaku individu. Siswa juga menjadi lebih aktif dan meningkatkan rasa ingin tau yang tinggi dalam mengetahui berbagai penyebab yang terjadi di bumi. Mereka melihat secara langsung dengan indera mereka sendiri sehingga menciptakan sensasi yang tidak dapat mereka lupakan yang menjadi pengalaman langsung.

Proses kegiatan belajar mengajar di kelas sering kali dikaitkan dengan makna hasil tujuan dari peningkatan pengetahuan lingkungan sedangkan pengalaman lapangan justru lebih berkorelasi tinggi dengan peningkatan pengaruh yang secara tidak langsung dengan meningkatkan perilaku dengan mengaktifkan pengetahuan yang didapatkannya. Di Louisiana, (Amerika Serikat) guru hortikultura menemukan bahwa siswa yang mengikuti program dengan komponen outdoor lebih sadar akan peran mereka di lingkungan daripada siswa yang tidak berpartisipasi dalam program (Stevenson et al., 2013). 


\section{Urgensi Penerapan Outdoor Learning dalam Praktik Pendidikan Lingkungan - Aminah Zuhriyah DOI: https://doi.org/10.31004/edukatif.v3i6.1662}

Pendidikan lingkungan (EE) harus dapat terus fokus pada peningkatan ekologi masyarakat berpengetahuan untuk mendorong tindakan berkelanjutan. Pendekatan defisit ini mengdanaikan bahwa sekali diberitahu tentang kerusakan lingkungan, orang akan bekerja menuju solusi berkelanjutan untuk masyarakat yang sehat. Penelitian juga menunjukkan bahwa pengetahuan tentang isu-isu lingkungan tidak cukup untuk memacu perilaku pro-lingkungan. Pendidikan lingkungan tradisional (EE) sebagian besar tidak berhasil dalam mencapai tujuannya mewujudkan praktik dan institusi yang ramah lingkungan. Untuk itu, diperlukan pendekatan pedagogis baru dengan aksi partisipatif melalui praktik langsung oleh para siswa tersebut. Reformasi kebijakan harus mendorong para pendidik untuk memasukkan kesempatan belajar yang partisipatif dan berorientasi pada tindakan yang memungkinkan siswa menerapkan pengetahuan mereka untuk memperbaiki masalah lingkungan dunia nyata.

Keberlanjutan telah menjadi kata kunci dalam pendidikan lingkungan (EE). Dari pendidikan anak usia dini hingga perguruan tinggi, siswa semakin belajar tentang masalah lingkungan dan bagaimana dampaknya terhadap kesehatan dan kesejahteraan manusia. Tujuan EE adalah untuk meningkatkan pengetahuan lingkungan masyarakat untuk mendorong mereka mengadopsi perilaku pro-lingkungan (Bywater, 2014). Lalu, juga adanya dampak positif program lingkungan terpadu teknologi (Green Technology) terhadap pengetahuan dan sikap siswa terhadap pemanfaatan teknologi dalam pendidikan luar ruang mendukung pengembangan pendidikan lingkungan. Pelajaran dilakukan dalam kelompok kecil, mendorong pendampingan sejawat sehubungan dengan penggunaan alat dan pengamatan yang mendorong kerja tim dalam kelompok pusat pembelajaran sains informal (ISL) (Hougham et al., 2018).

Pendidikan keberlanjutan transformatif (TSE) adalah praktik pedagogis yang telah terbukti memiliki dampak positif dan tidak biasa pada pembelajaran siswa dan perubahan perilaku. Kontribusi terakhir yang diperoleh selain berbagi pengetahuan siswa dan mendorong sikap pro lingkungan yang disosialisasikan kepada masyarakat sekitar sebagai bagian penting dari pembelajaran di luar ruangan (Gal \& Gan, 2021).

Apresiasi motivasi di balik tindakan lingkungan dan nilai-nilai praktis akan mendukung pemikiran ekosentris dalam meningkatkan filosofi lingkungan. Filosofi lingkungan yang harus ditekankan oleh pendidik adalah ekosentrisme yang merupakan pdanangan bahwa manusia bukanlah pusat dari alasan keberadaan planet, dan "lingkungan secara intrinsik bernilai". Kemudian, tindakan ekosentris sebagai "satu di mana alasan untuk bertindak adalah pemberian manfaat bagi lingkungan" yang terdengar sangat mirip dengan konservasi, yang dapat didefinisikan sebagai pengelolaan dan perlindungan alam untuk kepentingan makhluk hidup dan ekosistem yang memiliki manfaat. hak bawaan untuk hidup dan berkembang.

Meskipun mungkin benar bahwa sebagian besar perilaku yang merusak lingkungan adalah antroposentris, tidak tepat untuk mengklaim bahwa sikap antroposentris saja menyebabkan tindakan destruktif. Ekosentris umumnya mengakui premis antroposentris bahwa alam memiliki nilai karena melayani kepentingan manusia. Keberatan mereka terhadap antroposentrisme adalah bahwa antroposentrisme menegaskan bahwa alam hanya memiliki nilai sejauh ia melayani kepentingan manusia. Dari perspektif ekosentris, antroposentrisme gagal mengakui bahwa alam juga memiliki nilai yang terlepas dari kebutuhan manusia. Dengan kata lain, ekosentris bukanlah pemikiran antroposentris yang sepenuhnya salah; mereka pikir antroposentris hanya setengah benar (Cocks \& Simpson, 2015)

Untuk alasan inilah, pendidikan lingkungan harus dipahami sebagai 'proses pembelajaran di mana individu memperoleh kesadaran' lingkungan mereka, memperoleh pengetahuan, keterampilan, nilai-nilai dan pengalaman, yang pada gilirannya akan memungkinkan mereka untuk bertindak secara individu dan kolektif untuk memecahkan masalah lingkungan. Literatur dalam pendidikan lingkungan juga menekankan pengaturan pembelajaran yang spesifik, seperti pengaturan pembelajaran interaktif dengan alam, berpusat pada peserta didik, partisipatif, dan berorientasi pada tindakan yang berorientasi pada masa depan yang berkelanjutan. Untuk itulah pendidikan luar ruang sebagai salah satu penentu keberhasilan program pendidikan lingkungan di sekolah tersebut. Sekolah harus mempunyai rancangan strategi dalam mengelola pendidikan luar ruang agar dapat dipahami secara tepat untuk peningkatan perubahan sikap pro lingkungan. Guru sebagai fasilitator 
pendamping dalam pengelolaan program pendidikan ini juga harus berkomitmen penuh dan berperan aktif dalam mengatasi berbagai permasalahan lingkungan yang terjadi. Menciptakan ide dan solusi terpercaya yang semakin menginspirasi para siswa agar dapat merubah perilakunya. Salah satu bukti temuan yang dilakukan pada sekolah Al Fajar Bekasi ini menjadi titik temu dalam mendukung pendidikan lingkungan secara efektif. Kolaborasi aktif dari semua pihak terkait yang mendukung terciptanya pendidikan luar ruang ini terbukti menjadi penentu kesuksesan pengembangan pendidikan lingkungan. Memang kita tidak dapat melakukan dengan proses yang cepat namun, dengan kerja keras dan usaha aktif dari semua pihak maka akan terjadi perubahan dari perilaku para siswa tersebut sehingga dapat mengubah tatanan sekolah ramah lingkungan menjadi berkualitas dan sejalan dengan konsep Education for Sustainable Development (ESD).

Demikian juga, belajar dalam pengaturan kompleks yang menghubungkan teori dan praktik baik secara lokal maupun global adalah bagian penting dari Education for Sustainable Development (ESD). Sekolah dan lembaga pendidikan memberikan kesempatan untuk menanamkan perspektif global di sekolah alam sehingga mereka berkontribusi penuh pada penciptaan SDGs. Singkatnya, literatur pendidikan lingkungan menunjukkan bahwa di satu sisi bertujuan untuk menumbuhkan pengetahuan, kompetensi, dan nilai-nilai yang selaras dengan pembangunan berkelanjutan dan untuk menciptakan pengaturan yang efektif untuk pembelajaran alam itu. Untuk itulah penerapan outdoor learning menjadi komponen utama pendukung dalam terwujudnya kesuksesan praktik pendidikan lingkungan di sekolah secara efektif dan efisien yang dapat mengubah perilaku siswa menjadi agen perubahan untuk masa depan lingkungan bumi yang lebih baik dengan kolaborasi aktif dari semua stakeholder terkait seperti yang telah dilakukan oleh Sekolah Islam Al Fajar tersebut.

\section{KESIMPULAN}

Pentingnya pendidikan luar ruang akan semakin memacu siswa untuk berpikir kritis dan kreatif dalam mendukung keberlanjutan secara langsung. Siswa akan semakin berusaha untuk terus menjaga lingkungan alam dengan perilakunya di sekolah. Tujuan akhirnya adalah untuk mengubah persepsi dan perilaku siswa dengan bukti nyata dari tindakan mereka sesuai dengan konsep pendidikan lingkungan. Peran utama guru yang memberikan stimulasi berupa pengalaman dan pengetahuan yang dipadukan dengan praktik langsung akan semakin menunjang efektifitas pendidikan lingkungan. Memfokuskan pada isi praktik pengajaran dan pembelajaran langsung dari segi konteks jelas penting bagi pendidik lingkungan mengingat apa yang diketahui tentang bagaimana orang belajar seperti yang telah dilakukan oleh Sekolah Islam Al Fajar Bekasi. Penting dingat bahwa perhatian utama pendidik global adalah sejauh mana pendidikan melayani kepentingan publik global. Komitmen ini yang dibawa dan dijalankan oleh Sekolah ini. Kolaborasi aktif dari semua pihak yang terkait baik internal dan eksternal menjadi factor pendukung Sekolah Islam Al Fajar ini untuk menjadi berhasil.

Untuk mempromosikan identifikasi praktis, namun tetap sejalan konseptual dengan keterhubungan global, Sekolah Islam Al Fajar sendiri mengusulkan bahwa siswa harus terlibat, setiap tahun ajaran, dalam percakapan yang memulai pemahaman bahwa dunia melampaui sekolah dan komunitas asal mereka. Interaksi yang bertujuan ini mendukung siswa untuk memahami bahwa dunia lokal mereka berinteraksi dalam lingkungan global yang terhubung secara politik, sosial, dan ekonomi di seluruh planet ini. Siswa belajar bahwa apa yang mereka lakukan di rumah dan komunitas mereka memengaruhi orang lain dan lingkungan di seluruh dunia. Dengan demikian, masa pendidikan formal dasar merupakan masa untuk membangun dasar bagi pengembangan kompetensi Lingkungan lebih lanjut. Sekolah bukan hanya sebagai wahana dalam memberikan pertukaran transformasi ilmu saja, melainkan juga membentuk karakteristik yang berintegrasi untuk kemajuan khalayak ramai secara positif. Pendidikan yang efektif akan terus mendorong siswa untuk aktif dan bertanggung jawab dalam berbagai masalah lingkungan yang semakin kompleks. Pada akhirnya pendekatan pedagogis luar ruang akan memiliki potensi tinggi untuk mengintegrasikan fitur-fitur utama dan mengomentari beberapa pengalaman yang memberikan kesempatan kepada siswa untuk menjadi agen 
5181 Urgensi Penerapan Outdoor Learning dalam Praktik Pendidikan Lingkungan-Aminah Zuhriyah DOI: https://doi.org/10.31004/edukatif.v3i6.1662

perubahan di komunitas lokal mereka. Dengan bukti nyata tersebut sekolah ini telah menjadi tiang penentu keberhasilan dalam pencapaian pendidikan untuk pembangunan berkelanjutan (Education for Sustainable Development).

\section{KETERBATASAN PENELITIAN}

Keterbatasan dalam penelitian ini sendiri terbagi dari beberapa bagian yakni; Pertama dari kajian metode penelitian dikarenakan hanya fokus menggunakan metode penelitian kualitatif kajian fenomenologi, sehingga hasil temuan penelitian tersebut tidak dapat terukur secara pasti atau hasil angka yang dapat diuji keabsahan data yang bersifat numerik. Kedua dari kajian sasaran atau obyek penelitian yang hanya difokuskan ke satu sekolah dengan lingkup sekolah swasta saja, sehingga tidak dapat memberikan perbandingan temuan dengan sekolah lainnya dari berbagai sudut pandang. Ketiga dari kajian teori yang diambil yakni peneliti focus ke bidang pendidikan lingkungan saja, sehingga belum dilakukan penelitian mendalam lainnya apabila pendidikan luar ruang untuk digunakan pada aspek multidisiplin ilmu lainnya seperti misalnya pendidikan olahraga, seni, bahasa, matematika, kesehatan, social, dan cabang bidang ilmu lainnya.

\section{UCAPAN TERIMA KASIH}

Penulis ingin mengucapkan terima kasih kepada semua reviewer yang memberikan masukan berharga mereka untuk naskah dan membantu dalam menyelesaikan tulisan ini.

\section{DAFTAR PUSTAKA}

Adams, C., \& Van Manen, M. A. (2017). Teaching Phenomenological Research and Writing. Qualitative Health Research, 27(6), 780-791. https://doi.org/10.1177/1049732317698960

Asah, S. T., Bengston, D. N., Westphal, L. M., \& Gowan, C. H. (2018). Mechanisms of Children's Exposure to Nature: Predicting Adulthood Environmental Citizenship and Commitment to Nature-Based Activities. Environment and Behavior, 50(7), 807-836. https://doi.org/10.1177/0013916517718021

Bywater, K. (2014). Investigating the benefits of participatory action research for environmental education. Policy Futures in Education, 12(7), 920-932. https://doi.org/10.2304/pfie.2014.12.7.920

Cocks, S., \& Simpson, S. (2015). Anthropocentric and Ecocentric: An Application of Environmental Philosophy to Outdoor Recreation and Environmental Education. Journal of Experiential Education, 38(3), 216-227. https://doi.org/10.1177/1053825915571750

Coldwel, D. F., \& Evans, K. L. (2017). Contrasting effects of visiting urban greenspace and the countryside on biodiversity knowledge and conservation support. PLoS ONE, 12(3), 1-18. https://doi.org/10.1371/journal.pone.0174376

Eilam, E., \& Trop, T. (2014). Factors Influencing Adults' Environmental Attitudes and Behaviors and the Role of Environmental Schools in Influencing Their Communities. Education and Urban Society, 46(2), 234-263. https://doi.org/10.1177/0013124512447100

Evans, H. J., \& Achiam, M. (2021). Sustainability in out-of-school science education: identifying the unique potentials. Environmental Education Research, 27(8), 1192-1213. https://doi.org/10.1080/13504622.2021.1893662

Gal, A., \& Gan, D. (2021). Transformative Sustainability Education in Higher Education: Activating Environmental Understanding and Active Citizenship Among Professional Studies Learners. Sustainability, 13, 5758, 1-25. https://doi.org/10.1177/1541344620932310

Haas, C., \& Ashman, G. (2014). Kindergarten children's introduction to sustainability through transformative, experiential nature play. Australasian Journal of Early Childhood, 39(2), 21-29. https://doi.org/10.1177/183693911403900204

Harris, F. (2017). Developing a relationship with nature and place: the potential role of forest school. Plos 
5182 Urgensi Penerapan Outdoor Learning dalam Praktik Pendidikan Lingkungan - Aminah Zuhriyah DOI: https://doi.org/10.31004/edukatif.v3i6.1662

One, 12(3), 1-8. https://doi.org/10.1080/13504622.2021.1896679

Hougham, R. J., Nutter, M., \& Graham, C. (2018). Bridging natural and digital domains: Attitudes, confidence, and interest in using technology to learn outdoors. Journal of Experiential Education, 41(2), 154-169. https://doi.org/10.1177/1053825917751203

Kaklamanou, D., Jones, C. R., Webb, T. L., \& Walker, S. R. (2015). Using Public Transport Can Make Up for Flying Abroad on Holiday: Compensatory Green Beliefs and Environmentally Significant Behavior. Environment and Behavior, 47(2), 184-204. https://doi.org/10.1177/0013916513488784

Khusna, S. N. I., Djazilan, S., Ibrahim, Muslimin, Rahayu, \& Widiana, D. (2021). Dampak Sekolah Satu Atap terhadap Pola Perilaku Siswa di Sekolah Dasar. 3(6), 3553-3563.

Lochner, J. (2021). Developing a relationship with nature and place: the potential role of forest school. Environmental Education Research, 1-15. https://doi.org/10.1080/13504622.2021.1921116

Lochner, J., \& Robischon, M. R. 2 and M. (2015). Anthropocentric and Ecocentric: An Application of Environmental Philosophy to Outdoor Recreation and Environmental Education. Journal of Experiential Education, 38(3), 216-227. https://doi.org/10.3390/su13105758

Miller, N. C., Kumar, S., Pearce, K. L., \& Baldock, K. L. (2021). The outcomes of nature-based learning for primary school aged children: a systematic review of quantitative research. Environmental Education Research, 27(8), 1115-1140. https://doi.org/10.1080/13504622.2021.1921117

Pollock, K., Warren, J., \& Andersen, P. (2017). Inspiring environmentally responsible preschool children through the implementation of the national quality framework: Uncovering what lies between theory and practice. Australasian Journal of Early Childhood, 42(2), 12-19. https://doi.org/10.23965/AJEC.42.2.02

Pradina, Q., \& Faiz, A. Y. (2021). Peran Guru dalam Membentuk Karakter Disiplin ( Studi Pada Siswa di Mi Nihayatul Amal Gunungsari Cirebon ). EDUKATIF: JURNAL ILMU PENDIDIKAN Research, 3(7), 4118-4125.

Reid, A., Dillon, J., Ardoin, N., \& Ferreira, J. A. (2021). Scientists' warnings and the need to reimagine, recreate, and restore environmental education. Environmental Education Research, 27(6), 783-795. https://doi.org/10.1080/13504622.2021.1937577

Spiteri, J. (2020). Too Young to Know? A Multiple Case. Research, 14(1), 61-77.

Stevenson, K. T., Peterson, M. N., Bondell, H. D., Mertig, A. G., \& Moore, S. E. (2013). Environmental, Institutional, and Demographic Predictors of Environmental Literacy among Middle School Children. PLoS ONE, 8(3). https://doi.org/10.1371/journal.pone.0059519

White, R. L., Eberstein, K., \& Scott, D. M. (2018). Birds in the playground: Evaluating the effectiveness of an urban environmental education project in enhancing school children's awareness, knowledge and attitudes towards local wildlife. PLOS ONE, 13(3), 1-23. https://doi.org/10.1371/journal.pone.0193993

Wolsey, T. D. (2014). School Gardens : Situating Students Within a Global Context thomas devere wolsey, university of central florida, and diane lapp, san diego state university. J O URNALOFEDUCA T I O N, 194(3), 53-60.

Zebua, S. N., \& Siahaan, E. (2021). Pengaruh Kecerdasan Emosional , Kreativitas , dan Kemampuan Menyesuaikan Diri terhadap Kinerja Guru SMA. Jurnal Ilmu Pendidikan, 3(6), 3509-3519.

Zuiker, S. J., \& Riske, A. K. (2021). Growing garden-based learning: mapping practical and theoretical work through design. Environmental Education Research, 27(8), 1152-1171.

https://doi.org/10.1080/13504622.2021.1888886 